Instructions for authors, subscriptions and further details:

\title{
Academic Performance and Other Psychological, Social and Family Factors in Compulsory Secondary Education Students in a Multicultural Context
}

Miguel Ángel Broc ${ }^{1}$

1) Universidad de Zaragoza, Spain

Date of publication: February $25^{\text {th }}, 2018$

Edition period: February 2018-June 2018

To cite this article: Broc, M.A. (2018). Academic Performance and Other Psychological, Social and Family Factors in Compulsory Secondary Education Students in a Multicultural Context, International Journal of Sociology of Education, 7(1), 1-23. doi: 10.17583/rise.2018.2846

To link this article: http://dx.doi.org/10.17583/rise.2018.2846

PLEASE SCROLL DOWN FOR ARTICLE

The terms and conditions of use are related to the Open Journal System and to Creative Commons Attribution License (CC-BY) 


\section{Academic Performance and Other Psychological, Social and Family Factors in Compulsory Secondary Education Students in a Multicultural Context}

Miguel Ángel Broc

Universidad de Zaragoza

(Received: 6 September 2017; Accepted: 2 January 2018; Published: 25 February 2018)

\section{Abstract}

This work aims to transfer research on academic achievement in compulsory secondary education (CSE) students (12-18 years) from personal factors to others of a psychosocial or sociological type, in a Spanish center with a high level of immigration, which welcome students from twenty eight nationalities whose percentage is about $60 \%$. A second objective was to develop a brief measurement instrument to predict academic achievement, being the main dependent variable the number of suspended subjects in all three course evaluations, finding an "optimal constellation of variables" which may be more likely to achieve better academic achievement. 317 students of Secondary Education were part of this research in a public center of Zaragoza (Aragon-Spain) who were given an "ad hoc" Family Settings, Psychosocial and Contextual Questionnaire" whose factorial analysis yielded three factors: Context Immigration, Family Settings and academic autobiographical history and study habits. Finally, we analyzed the differences found among students from different continents, trying to find sociocultural foundations and optimal conditions that can explain these differences. Further analysis allows us to glimpse a configuration of the most important variables that point to a hypothetical "academic success" in this educational field where there is great ethnic and cultural diversity.

Keywords: academic performance, compulsory secondary education, ethnic and cultural diversity, family settings, contextual

variables

2018 Hipatia Press

ISSN: 2014-3575

DOI: $10.17583 /$ rise. 2018.2846

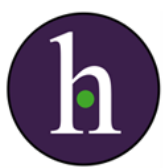




\section{Rendimiento Académico y Otros Factores Psicológicos, Sociales y Familiares en Estudiantes de Educación Secundaria Obligatoria en un Contexto Multicultural}

Miguel Ángel Broc

Universidad de Zaragoza

(Recibido: 6 Septiembre 2017; Aceptado: 2 Enero 2018; Publicado: 25 Febrero 2018)

\section{Resumen}

En este trabajo se intentó abordar el problema del rendimiento académico en alumnos de educación secundaria obligatoria (12-18 años) desde perspectivas más sociológicas, psicosociales o contextuales relativamente alejadas de modelos personales-endógenos, con el fin de encontrar variables o factores supuestamente más relacionados con las culturas y costumbres de los alumnos de un centro público de enseñanza secundaria de Zaragoza (España) multicultural, con alto nivel de inmigración y con alumnos de hasta veintiocho nacionalidades distintas. 317 alumnos formaron parte de esta investigación diseñándose un cuestionario "ad hoc" de Configuraciones Familiares, Psicosociales y Contextuales cuyo análisis factorial arrojó tres factores: Contexto de Inmigración, Configuración Familiar e Historia autobiográfica académica y hábitos de estudio. El programa Lisrel arrojó unos índices de bondad de ajuste del modelo justos pero suficientes. Finalmente, se analizaron las diferencias existentes encontradas entre los alumnos de los distintos continentes, tratando de extraer las condiciones óptimas donde puede ser más probable conseguir un hipotético éxito académico, mostradas a través del análisis de varianza de un factor.

Palabras clave: logro académico, educación secundaria obligatoria, diversidad étnica y cultural, configuraciones familiares, variables contextuales. 


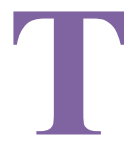

he search for causal relationships between independent variables and academic performance is a complex and elusive issue as smoke that looks, smells, feels, but when you want to catch fades and you are out of hand. Although from a historical point of view, initially many empirical studies have been carried out starting from inherent to the subject endogenous independent variables, from the psychology of traits (Broc, 2015; Schuerger, 2005), or from prospects intelligence and skills based on a differential and psychometric approach (Andrés, 1996), many studies based on these approaches, which correlate certain variables with other not usually arrive generally overcome explaining about $50 \%$ of the variance of change in the dependent variables (in our case performance), from independent, so a new search for factors and variables that help explain the relationships from paradigms or more ecological approaches (Bronfenbrenner, 1979) believe necessary, cultural (Bruner, 1990; Cole, 1992, 1999) or contextual (Valsiner \& Winegar, 1992; Cohen \& Siegel, 1991; Lacasa, 1994), which provide new data to progress in the construction of new more comprehensive theoretical models and integrators in this line.

The issue of academic performance has always figured prominently in the social and educational countryside and its relationship with certain mediating variables such as self-concept (Broc, 2000, 2014; Harter, 2012), motivation and volition (Broc, 2006, 2012), or from more complex theoretical models (Broc, 2011, 2017), etc., which supposedly affect it, still many factors that influence, reaching the conclusion that this relationship is multi-causal and affects different planes or levels of analysis. The number of publications on this construct is very high and we do not intend here to make any systematic review and meta-analysis studies, but to clarify the incidence of other more peripheral or secondary variables but no less important. A set of family, psychosocial and contextual variables "a priori" are considered, which can affect performance so this study be framed within a closer evolutionary paradigm to ecological perspectives and life cycle arises in this work, but also with elements of quantitative and correlational approach ( "ex post facto").

\section{Objectives}

1) Design and test the effectiveness of a measuring instrument family- 


\section{Broc-Academic Performance}

psychosocial variables, and context in compulsory secondary education students designed "ad hoc" and reduce the dimensions by analysis of categorical principal components, or in its ordinary case.

2) Empirically detect independent variables that enter into the equation predicting academic performance, detected by analyzing categorical or linear regression, based on an analysis of previous correlation between them.

3) To analyze the impact of family and contextual on academic performance and find variables, if possible, a constellation of "best" variables to predict a greater likelihood of success in school students and families in which they appear.

\section{Methods}

\section{Design}

The design of this study is retrospective "ex post facto" because the independent and dependent variables are already given in advance and try to find or reconstruct the events back, possible causes or independent variables that have caused the response (León \& Montero, 1998; Fontes de Gracia, García Garriga, Pérez-Llantada \& Sarriá, 2001).

\section{Participants}

The Center where conducted this research (IES El Portillo) is located at an average, medium-low area of Zaragoza capital and is representative as a public secondary school, one of the most diverse student presents all the Autonomous community. 317 high school students participated in this study, of whose 163 were men and 154 women. The racial courses were: $1=79(\mathrm{M}$ $=48$ and $31 \mathrm{~W}) ; 2 \mathrm{nd}=88(44 \mathrm{M}$ and $44 \mathrm{~W}) ; 3 \mathrm{rd}=78(34 \mathrm{M}$ and $44 \mathrm{~W})$; and $4=72(37 \mathrm{M}$ and $35 \mathrm{~W})$. The proportions do not differ significantly from each other at the .05 level.

The distribution by country of origin of the students was as follows: Algeria (1, 3\%), Brazil (2, 3\%), Bulgaria (1, 3\%), Chile (3, 9\%), China (7, $2.2 \%)$, Colombia $(6,1.9 \%)$, Costa Rica (1, 3\%), Cuba (2, 6\%), Dominican Republic (11, 3.5\%), Ecuador (24, 7.6\%), El Salvador (2, 6\%), Spain (145, 
45.7\%), Gambia (12 .3.8\%), Ghana (19, 6\%), Guatemala (4, 1.3\%), Guinea (6, 1.9\% ), Honduras (5, 1.6\%), Mali (1, 3\%), Morocco (4, 1.3\%), Mauritania (1, 3\%), Nicaragua (12, 3.8\%), Pakistan (1, 3\%), Palestine (1, $3 \%)$, Romania $(42,13.2 \%)$, Senegal $(2,6 \%)$, Tunisia (1, 3\%), Uruguay (1, $3 \%)$, Venezuela $(1, .3 \%)$.

Students grouped by Continents and sex were: Spain: 145 (76 M and 69 W); Eastern Europe: 42 (23 M and $19 \mathrm{~W}$ ); Asia: 9 (5 M and $4 \mathrm{~W}$ ); Central and South America: 74 (34 M and $40 \mathrm{~W}$ ); Africa: 47 (25 M and $22 \mathrm{~W}$ ). The number of immigrant children or children of immigrants is $175(55.2 \%)$ and native of $142(44.8 \%)$, not being significant difference in favor of either group $(F=3.061, p=.081)$. It can be said that the proportion of immigrants and natives is about the same. The number of students per course depending on the Continent is presented in Table 1.

Table 1

Number of students by class and by Continent

\begin{tabular}{lccccc}
\hline Continent & 1st CSE & 2nd CSE & 3rd CSE & 4th CSE & Total \\
\hline Spain & 41 & 25 & 39 & 40 & 145 \\
& $(12.9 \%)$ & $(7.9 \%)$ & $(12.3 \%)$ & $(12.65 \%)$ & $(45.7 \%)$ \\
Eastern & 6 & 19 & 10 & 7 & 42 \\
Europe & $(1.9 \%)$ & $(6 \%)$ & $(3.2 \%)$ & $(2.2 \%)$ & $(13.2 \%)$ \\
Asia & 2 & 3 & 2 & 2 & 9 \\
& $(0.6 \%)$ & $(0.9 \%)$ & $(0.6 \%)$ & $(0.6 \%)$ & $(2.8 \%)$ \\
Latin & 16 & 28 & 18 & 12 & 74 \\
American & $(5 \%)$ & $(8.8 \%)$ & $(5.7 \%)$ & $(3.8 \%)$ & $(23 \%)$ \\
África & 14 & 13 & 9 & 11 & 47 \\
& $(4.4 \%)$ & $(4.1 \%)$ & $(2.8 \%)$ & $(3.5 \%)$ & $(14.8 \%)$ \\
Total & 79 & 88 & 78 & 72 & 317 \\
& $(24.9 \%)$ & $(27.8 \%)$ & $(24.6 \%)$ & $(22.7 \%)$ & $(100 \%)$ \\
\hline
\end{tabular}

\section{Materials and Variables}

The material used is a questionnaire Family, psychosocial and contextual settings 30 issues whose variables take different values depending on their dichotomous nature or polytomous nominal, ordinal or interval, and is presented in Annex 1. The results of a exploratory factor analysis principal component, considering all the variables, ultimately, as numerical and 


\section{Broc-Academic Performance}

categorical analysis of other major components (CATPCA) optimal scaling type being subsequently presented fairly similar results.

The dependent variable was operationalized in two ways: a) Sum of scores (quantitative, continuous, numerical interval, with a range of 11 to 110 , since there are eleven subjects and the minimum score on each is one and the maximum ten); b) Number of failures, quantitative, numerical ratio, with the rank of zero-no suspense at-all eleven failures). The variable "number of failures" sheds $M=2.67$ and $S D=2.99$; the variable "sum of scores" an $M=51.60$ and $S D=18.64$, and the same variable "typified sum of scores" an $M=0.00$ and $S D=1$. Kolmogorov-Smirnov test for a sample applied to this variable in triple format a statistics throws 20 (Sig., $p<.00$ ) .06 (Sig., $p<0.00$ ) and .06 (Sig., $p<0.00$ ), respectively (correction Lilliefors in significance), adjusting to a normal curve.

\section{Typology of Independent Variables}

1-2: ordinal; 3-6: nominal; 7:ordinal/interval; 8: polytomous nominal later dichotomized; 9: nominal dichotomous; 10-13: ordinal / interval; 14-15 polytomous nominal later dichotomized, 16-20: nominal dichotomous; 21: interval; 22-30: nominal dichotomous.

\section{Procedure}

The questionnaire was designed considering contextual variables and peripheral struggling with the guardians of all courses of the ESO and modifying some items that might be somewhat confusing or unclear was designed. Subsequently, all prospective students of the Center administered at end of year (June 2015) mainly in tutorial hours. If a student / a it was not in the institute warned him and when he came to the beginning of the next course (several months later), was administered under the same conditions, in order to avoid the largest number of lost cases. The data was entered into the editor of SPSS, version 22, and proceeded to make all relevant statistical analysis. The final scores of students were obtained with the permission of the management team, the Board of teacher evaluation and reports of some students or their parents who did not consent to those who were asked in writing prior to administration discarded. 


\section{Results and Discussion}

In this research we used the statistical programs Spss (version 22) and Lisrel 8.51. First they were conducted a principal component analysis of the questionnaire, both categorical (CATPCA) and regular (EFA), in order to compare the results. Three main components are hypothesized. Later regression analysis all variables were performed, and after the most important on the dependent variable sum of qualifications and number of failures. Finally, analysis of variance of each variable was conducted separately, depending on certain factors, in order to deepen and better understand these variables. As the scaling level of the variables was numerically and the results were clearer, it chose to present data from the analysis of linear main components (exploratory), although the results were quite similar to those obtained by CATPA.

\section{Principal Components Analysis Exploratory twenty eight and twelve variables}

For all variables the $K M O=.76$, with Bartlett test of sphericity, with a Chisquare approximation of 2824,557, and $d f=378$; Sig. $=.00$, advised a factorization, to a solution of three factors. In a second analysis for the twelve variables selected with higher factor loadings, the $K M O$ was similar to perform a factorization $(K M O=.749$; Bartlett test of sphericity $=$ $1827,589, d f=66, S i g=.00$. Results obtained using variables 28 and 12 (in brackets) are shown in Table 2 (Extraction Method: Principal Component Analysis; Rotation Method: Promax with Kaiser Normalization).

One could conclude that a reduction of 28 items to 12 increases the total explained variance of $35 \%$ to $62 \%$ and that these elements can be grouped into 3 main factors: Factor Context of Immigration, with four items including continent of origin, born or not in Spain, being an immigrant or child of immigrant versus native and time in years of residence in Spain in three sections (1-6, 7-12 and 13-19 years). The second factor Family settings, that would include three items: family size, number of siblings and ordinal place that occupies at birth. The third and final factor called Academic autobiographical history and study habits, with five items that include daily hours of study, whether or not repeat a course in primary 


\section{Broc-Academic Performance}

and/or secondary education, whether or not study weekends and finally, negative attitude towards motivating study. The goodness of fit indices of the model are presented in Table 3 . 
Table 2.

Principal Components Analysis of 28 and 12 variables, and their corresponding structure matrix (correlations of the reduced matrix in brackets).

\begin{tabular}{|c|c|c|c|}
\hline Component & $\begin{array}{l}\text { Extraction Sums of } \\
\text { Squared Loadings } \\
\text { Total } \\
\end{array}$ & $\begin{array}{l}\text { Extraction Sums of } \\
\text { Squared Loadings } \\
\% \text { of Variance }\end{array}$ & $\begin{array}{l}\text { Extraction Sums of } \\
\text { Squared Loadings } \\
\text { Cumulative } \% \\
\end{array}$ \\
\hline 1 & $5.09(3.77)$ & $18.19(31.39)$ & $18.19(31.39)$ \\
\hline 2 & $2.51(1.98)$ & $8.95(16.52)$ & $27.14(47.91)$ \\
\hline 3 & $2.17(1.67)$ & $7.76(13.91)$ & $34.89(61.82)$ \\
\hline Variables & Component 1 & Component 2 & Component 3 \\
\hline Number of brothers & ,19 & ,25 & ,73 (.90) \\
\hline Busy place &, 05 &, 21 &, $50(.73)$ \\
\hline Grade level &,- 12 &,- 14 &, 00 \\
\hline Sex &, 04 &,- 04 &, 21 \\
\hline Continent & ,86 (.88) & ,35 (-.29) &, $25(.36)$ \\
\hline Spanish Nationality & ,93 (-.96) & ,32(-.28) &, 00 \\
\hline $\begin{array}{l}\text { Inmigrant or son of } \\
\text { inmigrant }\end{array}$ &,$- 93(.95)$ &,$- 34(.30)$ &,- 02 \\
\hline Separated parents &,- 21 &,- 34 &, 35 \\
\hline Family size &, 15 & ,12 &, $76(.71)$ \\
\hline Breakfast (yes or not) &, 37 &, 44 &, 07 \\
\hline Parents are gone &,- 14 &,- 15 & ,24 \\
\hline Parents help the study &, 34 &, 39 &, 05 \\
\hline $\begin{array}{l}\text { Father and mother } \\
\text { return home late }\end{array}$ &,- 27 &,- 25 &, 36 \\
\hline Daily hours of study &,- 16 &,$- 62(.69)$ &, 10 \\
\hline $\begin{array}{l}\text { The same daily hours } \\
\text { of study }\end{array}$ &, 13 &, 49 &, 19 \\
\hline At the same hours & ,24 & ,61 & ,06 \\
\hline Study room &, 30 & ,41 & 27 \\
\hline Father or mother help &, 25 & ,45 &,- 00 \\
\hline $\begin{array}{l}\text { Primary Education } \\
\text { repeated (one year) }\end{array}$ &,$- 24(.22)$ &,$- 40(.42)$ &,$- 33(-.42)$ \\
\hline $\begin{array}{l}\text { Secondary Education } \\
\text { repeat ( } 1 \text { or } 2 \text { years) }\end{array}$ &,$- 28(.27)$ &,$- 53(.63)$ &,- 00 \\
\hline $\begin{array}{l}\text { Week-End study at } \\
\text { home }\end{array}$ &, 18 &, $62(-.74)$ &,- 06 \\
\hline I like to study &,- 13 & ,43 &,- 20 \\
\hline $\begin{array}{l}\text { I want to stop } \\
\text { studying }\end{array}$ &,- 11 &,$- 58(.67)$ & ,08 \\
\hline Afternoon I'm alone &,- 25 &,- 22 & ,45 \\
\hline I live with my parents & ,20 & ,24 & 15 \\
\hline Mother works (or not) &, 00 &,- 07 & ,40 \\
\hline Father works (or not) &, 27 &, 33 &,- 01 \\
\hline $\begin{array}{l}\text { Residence time in } \\
\text { Spain }\end{array}$ &,$- 80(.82)$ &,- 21 &, 10 \\
\hline
\end{tabular}




\section{Broc-Academic Performance}

Table 3

Goodness of fit indices of the three factor model and twelve variables

\begin{tabular}{lllllllllll}
\hline$\chi^{2}$ & Df & $\chi^{2} / 2$ & RMSEA & GFI & AGFI & RMR & SRMR & NFI & NNFI & CFI \\
\hline \multirow{2}{*}{51.39} & \multirow{2}{*}{44} & 1.17 & 0.023 & & & & & & & \\
& & {$[0.0-$} & 0.97 & 0.95 & 0.067 & 0.042 & 0.97 & 0.99 & 1.00 \\
& $<3$ & $0.046]$ & & & & & & & \\
\hline
\end{tabular}

The $p$-value $=0.207$ (must be greater than .05 ) and the quotient between the Chi-square value and the degrees of freedom is less than three (1.17), and all other parameters conform to the established norm by Hooper, Coughlan and Mullen (2008), so it can be maintained that this model, in general, seems to fit quite well. A path diagram is shown in Figure 1.

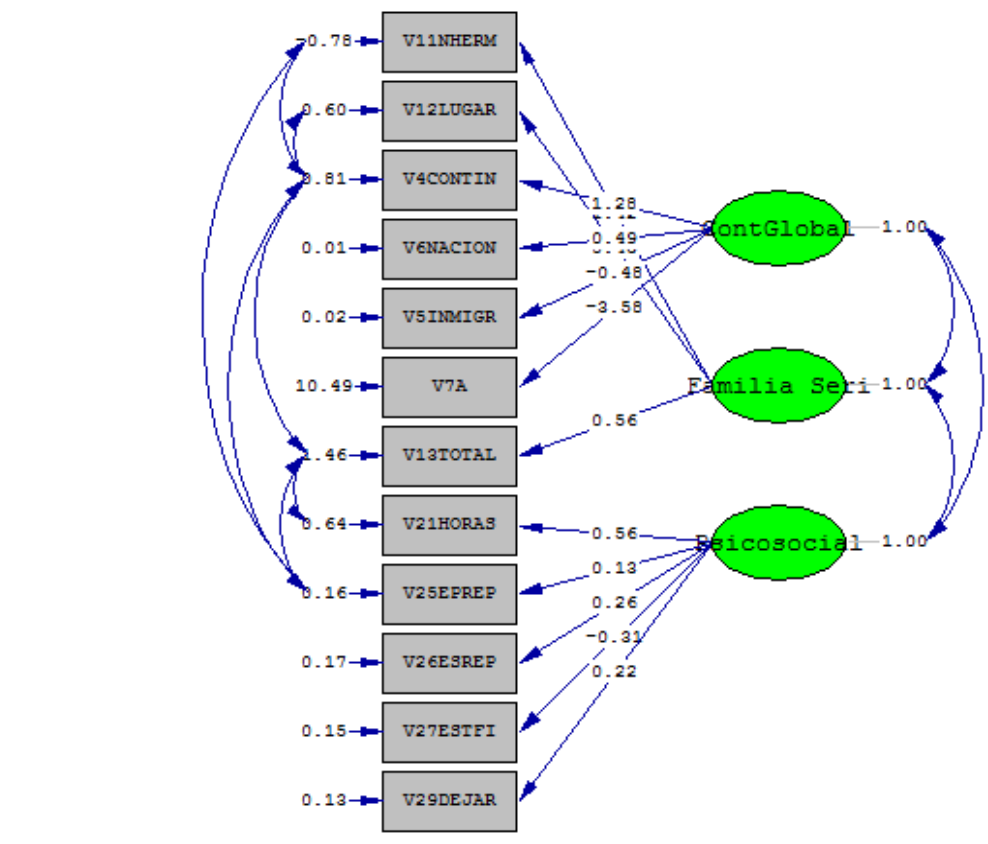

Chi-Square=51.39, $d f=44, \mathrm{P}-\mathrm{value}=0.20684, \mathrm{RMSEA}=0.023$

Figure 1. Path Diagram and model fit indices 


\section{Correlation Analysis}

Correlations between independent variables and the dependent variable number of failures and sum of scores are presented in Table 4.

Table 4. Correlations (Pearson) between independent variables with number of failures and sum of scores as dependent variables $(N=317)$

\begin{tabular}{|c|c|c|c|c|}
\hline Independent variable & $\begin{array}{l}\text { Number } \\
\text { of } \\
\text { failures }\end{array}$ & $\begin{array}{l}\text { Sig. } \\
\text { tailed })\end{array}$ & $\begin{array}{l}\text { Sum of } \\
\text { scores in } \\
\text { matters }\end{array}$ & $\begin{array}{l}\text { Sig. (2- } \\
\text { tailed) }\end{array}$ \\
\hline Number of brothers & .09 & .11 & $-.12 *$ & .03 \\
\hline Busy place & .05 & .38 & -.06 & .28 \\
\hline Country-Continent & $.29 * *$ & .00 & $-.33 * *$ & .00 \\
\hline Spanish nationality? & $.30^{* *}$ & .00 & $-.35^{* *}$ & .00 \\
\hline Inmigrant/or son/daughter of & $-.31 * *$ & .00 & $.36^{* *}$ & .00 \\
\hline Residence time in Spain & $-.33 * *$ & .00 & $.38 * *$ & .00 \\
\hline With whom I live at home? & $.23 * *$ & .00 & $-.28 * *$ & .00 \\
\hline Separated parents? & $-.15 * *$ & .00 & $.21 * *$ & .00 \\
\hline Number of separated years & .07 & .23 & $-.14 *$ & .02 \\
\hline Total family members & -.01 & .82 & -.02 & .72 \\
\hline Mother works? & .00 & .95 & -.03 & .57 \\
\hline Father works? & $.24 * *$ & .00 & $-.29 * *$ & .00 \\
\hline I eat breakfast every day? & $.28 * *$ & .00 & $-.27 * *$ & .00 \\
\hline Parents are gone & -.04 & .46 & .05 & .31 \\
\hline Parents return home late & $-.25 * *$ & .00 & $.26^{* *}$ & .00 \\
\hline Study hours & $-.28 * *$ & .00 & $.29 * *$ & .00 \\
\hline Study the same hours & $.13 *$ & .03 & -.09 & .11 \\
\hline Study at the same times & $.26^{* *}$ & .00 & $-.31 * *$ & .00 \\
\hline Study room & $.21^{* *}$ & .00 & $-.26 * *$ & .00 \\
\hline Parents help the study & $.19^{* *}$ & .00 & $-.21 * *$ & .00 \\
\hline Primary Education repeat (a year) & $-.26 * *$ & .00 & $.35 * *$ & .00 \\
\hline $\begin{array}{l}\text { Secondary Education repeat (one } \\
\text { or two years) }\end{array}$ & $-.41 * *$ & .00 & $.50 * *$ & .00 \\
\hline Week-End study at home & $.37 * *$ & .00 & $-.35^{* *}$ & .00 \\
\hline I like to study & .10 & .08 & -.11 & .06 \\
\hline I want to stop studying & $-.40 * *$ & .00 & $.38 * *$ & .00 \\
\hline Afternoon I'm alone & $-.15^{*}$ & .00 & $.18^{* *}$ & .00 \\
\hline
\end{tabular}




\section{Broc-Academic Performance}

\section{Regression Analysis}

If you select the dependent variable "number of failures", a regression analysis yields a model that includes 6 variables with a $R^{2}=0.358$, standard error of estimate $=2.41$ and a change in the significance of $F=.03$ (Durbin Watson $=1.98)$. The beta coefficients and the corresponding prediction equation are:

Number of failures $=10,807-1.75^{*}(I$ want to stop studying $)-1.29$ *(Repeated secondary education) - .62*(Residence time in Spain) + $.93 *$ (Week-End study at home) $-.99 *$ (Repeated primary Education) - .67 *(Parents return home late).

With the independent variable "Sum of grades" in all academic subjects, the model is as follows:

Table 5. Summary of Model ${ }^{h}$ of predictor variables on academic performance (Sum

\begin{tabular}{|c|c|c|c|c|c|c|c|c|c|c|}
\hline $\begin{array}{l}\text { Mo } \\
\text { del }\end{array}$ & $\mathrm{R}$ & $\mathrm{R}^{2}$ & $\begin{array}{l}\text { Adjusted } \\
\mathrm{R}^{2}\end{array}$ & $\begin{array}{l}\text { Std. Error } \\
\text { of } \\
\text { estimate }\end{array}$ & $\begin{array}{l}\text { Chang } \\
\text { e } \\
\mathrm{R}^{2}\end{array}$ & $\begin{array}{l}\text { Change } \\
\text { in } \mathrm{F}\end{array}$ & $\begin{array}{l}\mathrm{df} \\
1\end{array}$ & $\mathrm{df2}$ & $\begin{array}{l}\text { Sig. } \\
\text { F } \\
\text { Chan } \\
\text { ge }\end{array}$ & DW \\
\hline 1 &, 50 & 25 & 25 & 16,12 & 25 & 104,86 & 1 & 314 & , 00 & \\
\hline 2 &, 57 &, 33 &, 32 & 15,29 &, 07 & 35,91 & 1 & 313 &, 00 & \\
\hline 3 & ,62 & 38 &, 37 & 14,72 &, 05 & 26,08 & 1 & 312 &, 00 & \\
\hline 4 & ,65 &, 42 &, 42 & 14,21 &, 04 & 23,49 & 1 & 311 & ,00 & \\
\hline 5 & ,66 & ,44 &, 43 & 14,07 &, 013 & 7,31 & 1 & 310 &, 01 & \\
\hline 6 &, 67 & ,45 &, 44 & 13,93 & 013 & 7,07 & 1 & 309 &, 01 & \\
\hline 7 &, $67^{8}$ & ,46 & ,44 & 13,86 &, 01 & 4,08 & 1 & 308 &, 04 & 2,15 \\
\hline
\end{tabular}

g. Predictors: (Constant), Repeated Secondary Education, I want to stop of studying,

Residence time in Spain, Repeated Primary Education, Parents return home late, Father works, Week-End study at home

h. Dependent variable: Sum of grades 
Table 6. Beta coefficients of the prediction model over the "sum of grades" dependent variable

\begin{tabular}{|c|c|c|c|c|c|c|c|c|}
\hline Model & B & $\begin{array}{l}\text { Std. } \\
\text { Error }\end{array}$ & Beta & $\mathrm{t}$ & Sig. & $\begin{array}{l}95 \% \text { IC } \\
\text { for B } \\
\text { Lower } \\
\text { Bound }\end{array}$ & $\begin{array}{l}95 \% \text { IC } \\
\text { for B } \\
\text { Upper } \\
\text { Bound }\end{array}$ & $\begin{array}{l}\text { Corr. } \\
\text { Partial }\end{array}$ \\
\hline (Constant) & -.5 .19 & 7.61 & & -.68 & .49 & -20.18 & 9.80 & \\
\hline $\begin{array}{l}\text { Repeated } \\
\text { Secondary } \\
\text { Education }\end{array}$ & 11.26 & 1.76 & .30 & 6.39 & .00 & 7.79 & 14.74 & .34 \\
\hline $\begin{array}{l}\text { I want to stop of } \\
\text { studying }\end{array}$ & 9.06 & 2.04 & .20 & 4.43 & .00 & 5.04 & 13.08 & .25 \\
\hline $\begin{array}{l}\text { Residence time } \\
\text { in Spain }\end{array}$ & 4.35 & 1.02 & .19 & 4.28 & .00 & 2.35 & 6.35 & .24 \\
\hline $\begin{array}{l}\text { Repeated } \\
\text { Primary } \\
\text { Education } \\
\text { course }\end{array}$ & 9.16 & 1.92 & .21 & 4.77 & .00 & 5.38 & 12.95 & .26 \\
\hline $\begin{array}{l}\text { Parents return } \\
\text { home late }\end{array}$ & 4.37 & 1.78 & .11 & 2.45 & .01 & .86 & 7.88 & .14 \\
\hline Father works & -.4 .23 & 1.72 & -.11 & -2.46 & .01 & -7.61 & -.85 & -.14 \\
\hline $\begin{array}{l}\text { Week-end study } \\
\text { at home }\end{array}$ & -3.61 & 1.78 & -.10 & -2.02 & .04 & -7.12 & -.09 & -.11 \\
\hline
\end{tabular}

e. Dependent variable: Sum of all grades

This model with the variable "sum of grades" provides a $R^{2}=0.456$ (ANOVA, $F=36.89, \mathrm{p}<.00$ ) compared to the "number of failures" which is .358 , so we opted for the first. The prediction equation the sum final grade will be:

Sum of obtained grades $=-5.19+11.26 *$ Repeated Secondary Education + 9.06* I want to stop to studying $+4.35 *$ Residence time in Spain + 9.16*Repeated Primary Education course $+4.37 *$ Parents return home late $-4.23 *$ Father works $-3.61 *$ Week-end study at home.

\section{Analysis of Academic Performance}

The average of the sum of scores (grades) on immigrant students or children of immigrants is lower and statistically significant $M=45.62(S D=17.03)$ and $N=175$, compared to that of native students $M=58.97(S D=17.92)$ and $N=142 ; A N O V A, F=45.98 d f(1,315), p<.00$ Similar results are 


\section{Broc-Academic Performance}

obtained if used as the dependent variable the average number of failures (Spain $M=1.62, S D=2.44$; Eastern Europe $M=3.52, S D=3.26$; Asia $M=$ $1, S D=1.41$; Latin America $M=4.01, S D=3.25$; and Africa $M=3.34$ and $S D=2.81)$. There are statistically significant differences in the dependent variable average number of failures (or sum of obtained degrees), depending on the continents of the students or their families come from.

Levene statistic $=7.48, d f 1=4, d f 2=312$, Sig. $=.00$, ANOVA, $\mathrm{F}=11.78$ ( $d f 4$ 312) $p<.00$. Post Hoc test (tests LSD) and Tamhane yield statistically significant differences $(p<.05)$ from the following countries: Spain with all except Asia and the latter with all except Spain; Eastern Europe with Spain and Asia but not with America and Africa; America with Spain and Asia but not in Africa and Eastern Europe, and Africa with Spain and Asia but not in Eastern Europe and America. Three sections of variable time period is significant between the first period (1-6) years and two (7-12) and (13-19), but not between the latter two.

Academic performance (number of failures) is statistically significant in terms of the Separated Parents variable (Yes/No). For the children of separated parents $(N=104, M=3.32$ average of failures; $S D=3.26)$ compared to not separated $(N=213 ; M=2.35, S D=2.80)$. The way $A N O V A$ shows an $F=7.443, d f(1,315)$, Sig. $=.00$. The Levene statistic $=8.13$, Sig. $=0.005$, indicating that the variances are inhomogeneous samples between those students. Statistical Welch and Brown-Forsythe also showed statistical $p$ values $<.05$.

The average number of failures by course only provides statistically significant differences between the 4th year and everyone else, but not between 1 st to $3^{\text {rd }}$ taken in pairs (Post Hoc Test-LSD). This could indicate a general tendency of teachers to approve more students in order to promote and obtain the final qualification. It can be seen that the average number of failures is 1.58 in 4th year, interesting fact since obtaining the title is awarded to two subjects not overcome if it is considered that the student has achieved the minimum objectives. For first secondary education course $(N=$ $79, M=2.73$ and $S D=3.07)$, in 2nd $(N=88, M=2.80$ and $S D=2.89)$ in 3rd $(N=78, M=3.46, S D=3.20)$ and to 4 th $(N=72, M=1.58$ and $S D=2.47)$.

No statistically significant differences are showed in the variable number of failures by gender. For males $(N=163, M=2.74, S D=3.00)$ and women $(N=154, M=2.60, S D=2.98)$, with $F=.17, d f(1,315)$, Sig. $=.68$, 
although the sum of degrees variable itself that marks the difference is statistically significant and higher in women with an $M=53.75$ and $S D=$ 19.97, compared with an $M=49.57$ and $S D=17.10$ in males, being the value of $F=4.01$, and $\mathrm{Sig} .=.046$.

Both the number of failures as the sum of degrees are lower and higher, respectively, in students who eat breakfast every day $(N=214, M=2.08, S D$

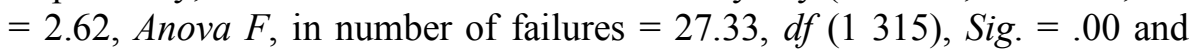
sum of scores obtained in the subjects, $M=55.07$ and $S D=18.21, F=$ 24.47 , Sig. $=.00)$, compared to those who do not eat breakfast daily $(N=$ $103, M=3.88$ and $S D=3.33$ ) in the variable number of failures and a $M=$ 44.40 and $S D=17.50$ in sum of scores in the matters. The latter almost double in the number of failures to students whose eat breakfast. Moreover, the percentage of immigrants who eat breakfast is $30 \%$ (95) and $37.5 \%$ (119) in the local population, and the percentage of those who do not eat breakfast every day is $25.2 \%$ (80) immigrants compared with $7.3 \%$ (23) in the locals. (Pearson Chi-Square $=31.14, d f 1$, bilateral asymptotic significance $=.00$.

No statistically significant differences in the dependent variables depending on whether the parents are gone or not to work in the morning before the child to go to school can be reported, although the number of failures slightly higher in children whose parents are gone and the sum of obtained scores in the matters lower.

However, significant differences can be reported in the dependent variables depending on whether or not parents help their children in school, look on the other hand, understandable. Children who are helped by one of their parents obtained an average of failures $M=1.90, S D=2.98, N=77$, compared with an $M=2.92, S D=2.95, N=240$, in children whose parents they do not help them or cannot help them. (ANOVA F $=6.93$, Sig. $=.009)$.

A similar pattern is observed if the variable Father and Mother come late to work is used. Students whose parents come late to work get a greater number of failures $(N=101, M=3.77, S D=3.22)$ and a lower sum of obtained scores in the matters $(M=44.57, S D=17.60)$, that students whose parents no return late at home $(N=216, M=2.15, S D=2.79)$ in number of failures, and $M=54.88$ and $S D=18.23$ in sum of scores obtained in matters, with $F=21.53$, Sig. $=.00$ and $F=22.49$, and Sig. $=.00$, respectively.

A surprising fact is the finding of no differences in study hours depending on the course, whose means are not significant between any 


\section{Broc-Academic Performance}

course of four that make up the stage. In first of secondary education $(N=$ $79, M=1.15, S D=.84)$, in $2 \mathrm{nd}(N=88, M=1.26, S D=.99)$ in $\operatorname{3rd}(N=78$, $M=1.54, S D=1.17)$ and in 4th $(N=72, M=1.29, S D=.81)$, with $F$ $(A N O V A)=2.24$, df 331 , and Sig. $=.08$. This indicates that students no longer study in subsequent academic years, but in all of them, the average number of hours devoted to the study is the same.

Moreover, students who study the same hours $(N=137, M=2.24$ and $S D$ $=2.56)$ also obtain a lower average number of failures, versus those who do $\operatorname{not}(N=180, M=2.99, S D=3.24)$, with an $F(A N O V A)=5.01, d f 1315$, Sig. $=.03$, although the sum of scores does not become significant.

In the variable studying at the same times, statistically significant differences between the two groups of students reappear. Those who have become accustomed to study at the same times $(N=139, M=1.78, S D=$ 2.35) obtained a smaller number of failures that those who study at different times $(N=178, M=3.17, S D=3.24)$ with an $F=23.64$, df 1315 , Sig. = $.00)$, and also get a larger sum of final marks the first $(M=58.6, S D=17.06)$ compared to those who study at different times $(M=46.56, S D=18.30)$, with $F=32.71$, Sig. $=.00$.

A similar pattern is obtained by comparing students to have a room to study in relation to which no. The first obtained an average number of failures lower $(N=251, M=2.34, S D=2.78)$ compared to those who do not $(N=66, M=3.91, S D=3.42), F=15.00, d f 1315, \mathrm{Sig} .=0.00$. And so does the sum of scores obtained in the matters for those who do have room $(M=$ $54.04, S D=17.99)$ compared to those without $(M=42.30, S D=18.24)$, with $F=22.13, p<.05$.

It may say the same with respect to variable repeated primary education. Students repeated gain greater number of failures $(N=74, M=4.08, S D=$ $3.19)$ than those who did not repeat a year $(N=243, M=2.24, S D=2.79)$, with $F=23.08, d f 1315$, Sig. $=.00)$. The first obtained a sum of scores in the matters lower $(M=39.88, S D=14.90)$ compared to those without $(M=$ $55.17, S D=18.21), F=43.29$, Sig. $=.00$.

These differences are similar, but more pronounced in the number of failures, if we compare students who have repeated a year in Secondary Education $(N=129, M=4.12, S D=3.2)$ compared to those without $(N=$ $188, M=1.67, S D=2.37)$, with $F=61.50$, df 1,315 , Sig. $=.00$. Similarly, in the sum of scores obtained in the matters, the repeaters $(M=40.29, S D=$ 
14.03) compared to those without $(M=59.36, S D=17.42)$, with $F=106.84$, Sig. $=.00$.

The comparison between the number of failures in the students studying the weekends $(N=185, M=1.74, S D=2.37)$ is lower than those who do not $(N=132, M=3.97, S D=3.27)$ with an $F=49.47, d f 1315$, and Sig. $=.00$. And conversely occurs with the sum of scores that is higher in the first $(M=$ $57.16, S D=17.61)$ compared to those without $(M=43.81, S D=17.25)$, with $F=45.00 ;$ Sig. $=.00$.

The comparison between students whose like to study and those who cannot provide a different pattern. In this case, no statistically significant differences between them are showed although students who like to study ( $N$ $=103, M=2.24$ and $S D=2.77$ ) the number of failures is slightly less than those who do not like $(N=214, M=2.87, S D=3.07)$, and similarly in the sum of scores obtained in the matters. This may be due to the set of response or to give socially acceptable answers. Even if that is true, the problem is that many students who say they like the study, do not have and/or implement motivational and volitional actions to start and complete the process, having internal resistance as the lack of habits study, lack of tolerance to frustration, lack of effort, delay gratification and affecting the implementation of the conduct in question. This phenomenon needs further investigation and has been treated elsewhere (Broc, 2012).

However the item referred to want to stop studying does not have connotations of social desirability and not all students are able to externalize it, even though it is implicit in them, yielding more clearly the performance, on the other hand, understandable. In this case, those who wish to stop studying $(N=71, M=4.92, S D=3.05)$ obtained a greater number of failures that students who do not want to leave the studies $(N=246, M=2.02, S D=$ 2.64), with $F=461.83, d f 1315$, Sig. $=.00$. The sum of scores obtained in the all matters is on the same line $(M=38.32, S D=15.94)$ versus what you do not want $(M=55.43, S D=17.59)$, with $F=52.25$, Sig. $=.00$, being higher in these last ones.

In the variable I'm home alone in the evenings, the same pattern as in the variable above is repeated. Those who are alone $(N=79, M=3.47, S D=$ 3.07) get higher failure rates than those with a parent $(N=238, M=2.40, S D$ $=2.92$ ), with $F=7.70, d f 1315$, Sig $=.00$, and in line with the sum of scores 


\section{Broc-Academic Performance}

in the first group $(M=45.86, S D=17.08)$, versus those who are not alone $(M=53.50, S D=18.77), F=10.27$, Sig. $=.001$.

In the variable $I$ live with my parents versus other configurations, repeats the same pattern. Those who live with both parents $(N=297, M=2.56, S D$ $=2.95)$ the average number of failures is less than those living in other family configurations $(N=20, M=4.25, S D=3.23)$, with $F=6.08$, Sig. = .014. Parallel in sum of scores in the matters, those living with both parents $(M=52.34, S D=18.47)$ compared to those without $(M=40.65, S D=$ 18.13), $F=7.52$, Sig. $=.006$.

In the case of working mother, the results are significant in the average number of failures in favor of working mother, compared to those who do not $(N=220, M=2.94, S D=3.15)$ compared to that the mother does not work $(N=97, M=2.05, S D=2.99)$. Regarding the sum of scores in the matters, differences are not statistically significant.

The pattern obtained when the father is working or not working is similar but also significant in the sum of scores. In the case of working $(N=211, M$ $=2.26, S D=2.81)$, the number of failures in the students is less than if it does not work $(N=106, M=3.48, S D=3.16), F=12.19$, Sig. $=0.00$, being sum of scores $M=54.92, S D=18.52$, in the case of work, compared to an $M$ $=44.99, S D=17.12$, in the case of not working, with $F=21.31$, and Sig. $=$ .00 .

\section{Number of Siblings and Family Size}

The average of failures depending on the number of siblings (four sections 1, 2, 3-5 and 6-9) shows an increasing trend of failures from the 2 nd brother on, but becomes significant, except between groups 2 and 3-5 brothers. A brother $(N=55, M=2.62, S D=2.92)$, two brothers $(N=160, M=2.33, S D$ $=2.97)$, three to five brothers $(N=94, M=3.22, S D=3.03)$ and six to ninth siblings $(N=8, M=3.38, S D=2.61)$. Bivariate correlations between the number of failures and the variable number of siblings is $r=.09(d f=315, p$ $=.11$ ) and the family size $r=-.013, d f=315,2$-tailed Sig. $=.82$. If the dependent variable sum of scores with the number of siblings is used, $r=-$ .12 , Sig. $=.03, d f=315$, and the family size $r=-.02$ Sig. $=.72$ and $d f=315$. Discretizing the variable number of siblings in 4 sections, the results are very similar. 
Moreover, the average of failures in the 3rd assessment based on the ordinal place of the student between brothers or sisters (4 sections: First, $N=$ $144, M=2.67, S D=2.95 ; 2$ nd N $=129, \mathrm{M}=2.51, \mathrm{SD}=3.02 ; 3 \mathrm{rd} \mathrm{N}=34, \mathrm{M}$ $=3.06, \mathrm{SD}=2.97$; and 4 or later $N=10, M=3.40, S D=3.44)$ ) is increased from the third but does not significant in ANOVA, whose $F=0.510$, Sig. $=$ .68 , and with a statistical test of the homogeneity of variance Levene $=.28$, Sig. $=.84$ and Robustness test of equality of means Welch $=.45$, Sig. $=.72$, so we can say that there is no difference between the means of the average number of failures of any ordinal brothers depending on the place of the student in the family.

Although the number of publications is quite extensive in this regard (Arranz, 1989; Rodrigo \& Palacios, 1998), but somewhat contradictory and inconclusive, the same could be said regarding the ordinal place of the son or daughter in the family (Cusinato, 1992; Sanchez, 1983), so further research is necessary, where the studies are carried out to take into account variables not controlled in this study as the short spacing or medium in birth time regarding his brothers, sex repeated or not in the group of brothers and if there are very important brothers or sisters who have already emancipated, variable because it can mask some results because you can have many brothers or sisters but no longer live in the nuclear family, which would change the constellation thereof. What is important ultimately is that all brothers or sisters find their own role in the family, for example his space of self-identification, in order not to have to look out, and develop more ingenious and intuitive procedures to find recognition within the family. The theme of fraternal rivalry, jealousy and envy, in some cases, remains a hot topic within the current family configurations.

\section{Conclusions}

The findings of this study on the variables that affect achievement and school success versus failure at the stage of compulsory secondary education (12-16 or 18 years old) in Spain are quite clear and obvious. In this sense, it could be argued that students, in this stage, would be in general, more likely to academic success, translated into fewer number o failures or greater sum of scores obtained in the academic matters, if the following circumstances occurred: 
1) Spanish or Asian students.

2) Man or woman of any course or level.

3) With a number of not more than 2 brothers, including himself.

4) The ordinal place is the first or the second.

5) No immigrant or child of immigrant parents.

6) With a minimum period of years in Spain 7 to 12, preferably.

7) That the student live at home with their biological parents and are not separated.

8) With a size of small family members.

9) With at least one parent working, preferably the father.

10) That parents do not come late to work.

12) The student to eat breakfast every day.

13) May a parent is available to assist the son or daughter in school.

14) Students will study more than one hour a day.

15) To study about the same time and at the same times every day.

16) Students will study the weekends.

17) Have a room to study.

18) Who has not repeated a course or year in primary or secondary education.

19) The student does not want to stop studying.

20) The student is not only at home in the evenings.

This research analyzed variables considered peripheral in other studies related to more personal aspects embedded in social, family and contextual situations that provide, through the measuring instrument studied, a moderate percentage of explained variance of academic performance. It would be interesting, to increase the validity of the model in future work including general intelligence variable and others, from the work done by Gaviria (2005), Castro \& Gaviria (2009), Martín et al., (2008), in which the inclusion of other variables is considered essential, as well as Enkvist's recommendations on good and bad education (Enkvist, 2011) in schools. This, perhaps provide a broader vision and accurate explanation of academic achievement in students of compulsory secondary education. 
RISE - International Journal of Sociology of Education, 7(1) 21

\section{References}

Álvaro, M., Bueno, M. J., Calleja, J. A. Cerdán, J., Echevarría, M. J., García, C., Gaviria, J. L., Gómez, C., Jiménez, S., López, B., Martín-Javato, M., Mínguez, A. L., Sánchez, A., \& Trillo, C. (1990). Hacia un modelo causal del rendimiento académico. Madrid: Centro de Publicaciones del Ministerio de Educación y Ciencia. CIDE. Andrés, A. (1996). Manual de Psicología Diferencial. Madrid: McGrawHill.

Arranz, E. (1989). Psicología de las relaciones fraternas. Barcelona: Herder.

Broc, M. Á. (2000). Autoconcepto, autoestima y rendimiento académico en alumnos de $4^{\circ}$ de ESO. Implicaciones psicopedagógicas en la orientación y tutoría. Revista de Investigación Educativa, 18(1), 119146.

Broc, M. Á. (2006). Motivación y rendimiento académico en alumnos de Educación Secundaria Obligatoria y Bachillerato LOGSE. Revista de Educación, 340, Mayo-Agosto 2006, 379-414.

Broc, M. Á. (2011). Voluntad para estudiar, regulación del esfuerzo, gestión eficaz del tiempo y rendimiento académico en alumnos universitarios. Revista de Investigación Educativa, 29(1), 171-185.

Broc, M. Á. (2012). Volición, Autorregulación y Aprendizaje. Implicaciones en el rendimiento académico y en la práctica educativa. Editorial Académica Española. Saarbrücken: Alemania: LAP LAMBERT Academic Publishing GmbH \& Co. KG.

Broc, M. Á. (2014). Harter's Self Perception Profile for Children: An adaptation and validation for the Spanish Version. Psychological Reports, 115(2), 444-466. doi:10.2466/08.07.PR0.115c22z5

Broc, M. Á. (2015). A longitudinal study of academic success and failure in compulsory secondary eduation and baccalaureate students through the Millon Adolescent Inventory (MACI). Psychology, 6, 1427-1437. doi:http://dx.doi.org/10.4236/psych.2015.612139

Broc, M. Á. (2017). Relationships between Motivational Self-Perception, Affect, and Academic Achievement in Students of Junior and Senior High School. In Jacob A. Sorensen \& Nikolaj S. Schultz (Eds). SelfPerception. Research Advances and Clinical Challenges. (pp. 127- 
171). New York: Nova Science Publishers, Inc. ISBN: 978-1-53612691-4.

Bronfenbrenner, U. (1979). The ecology of human development. Cambridge, Mass: Harvard University Press [Traducción castellana; La ecología del desarrollo humano. Barcelona, Paidós, 1987].

Bruner (1990). Acts of Meaning. Cambridge, MA: Harvard University

Press. [Traducción castellana: Actos del significado. Madrid: Alianza Editorial, 1991].

Castro, M., \& Gaviria, J. L. (2009). La evaluación educativa desde la perspectiva del valor añadido. Estudios sobre educación, 16, 147166.

Cohen, R., \& Siegel, A. W. (1991). A context for context: Toward an analysis of context and development. En R. Cohen \& A. W. Siegel (Eds.) Contexts and development. Hillsdale, NJ: Lawrence Erlbaum Associates.

Cole, M. (1992). Context, modularity, and the cultural constitution of development. En L. Winegar \& J. Valsiner (Eds.), Children's development within social context. Hillsdale N. Y.: Lawrence Erlbaum Associates.

Cole, M. (1999). Psicología cultural. Madrid: Morata. [Cole, M. (Sixth printing 2003). Cultural Psychology: a once and future discipline. Harvard University Press.

Cusinato, M. (1992). Psicología de las relaciones familiares. Barcelona: Herder.

Enkvist, I. (2011). La buena y la mala educación. Madrid: Ediciones Encuentro, S. A.

Fontes de Gracia, S., García, C., Garriga, A. J., Pérez-Llantada, M. C., \&

Sarriá, E. (2001). Diseños de Investigación en Psicología. Madrid. UNED.

Gaviria, J. L. (2005). Modelos jerárquicos lineales. Madrid: La Muralla. Harter, S. (2012). The Construction of the Self. Developmental and

Sociocultural Foundations. (Second Edition). New York London:

The Guilford Press. http://www.guilford.com

Hooper, D., Coughlan, J., y Mullen, M. (2008). Structural Equation

Modelling: Guidelines for Determining Model Fit. Electronic Journal of Business Research Methods, 6(1), 53-60. 
Lacasa, P. (1994). Aprender en la escuela, aprender en la calle. Madrid: Visor.

León, O. G., y Montero, I. (1998). Diseño de investigaciones. Introducción a la lógica de la investigación en Psicología y Educación. Madrid: McGraw-Hill.

Martín, E., Martínez-Arias, R., Marchesi, A., Pérez, E. (2008). Variables that Predict Academic Achievement in the Spanish Compulsory Secondary Education System: A Longitudinal Multi-Level Analysis. The Spanish Journal of Psychology, 11(2), 400-413.

Rodrigo, M. J., y Palacios, J. (Coords). (1998). Familia y Desarrollo Humano. Madrid: Alianza Editorial.

Sánchez, E. (1983). Los hermanos: convivencia, rivalidad, solidaridad. Madrid: Narcea.

Schuerger, J. M. (2005) Cuestionario de Personalidad para Adolescentes 16PF-APQ. Manual. (2 Edición). Adaptación española de N.

Seisdedos. Publicaciones de Psicología Aplicada. Madrid: TEA Ediciones S.A.

Valsiner, J. \& Winegar, L. T. (1992). "Introduction: A cultural-historical context for social context”. En L. T. Winegar \& J. Valsiner (Eds.). Children's development within social context, Hillsdale N. Y.: Lawrence Erlbaum.

Miguel Ángel Broc is professor at University of Zaragoza, Spain

Contact Address: mabroc@unizar.es 